\title{
TOKSISITAS SUBKRONIK EKSTRAK ETANOL UWI BANGGAI UNGU (Dioscorea alata L.) TERHADAP ENZIM SERUM GLUTAMAT OKSALOASETAT TRANSMINASE DAN SERUM GLUTAMAT PIRUVAT TRANSMINASE PADA TIKUS PUTIH (Rattus Novergicus) GALUR WISTAR SECARA IN VIVO
}

\section{SUB-CHRONIC TOXICITY OF PURPLE YAM (Dioscorea Alata L.) ETHANOL EXTRACT IN SERUM GLUTAMAT OXALOACETIC TRANSMINASE AND SERUM GLUTAMIC PYRUVIC TRANSMINASE OF WHITE RAT (Rattus Novergicus) IN VIVO}

\author{
CINDY RADIKASARI ${ }^{1 *}$, IHWAN ${ }^{1}$, RIRIEN HARDANI ${ }^{1}$ \\ ${ }^{1}$ Program Studi Farmasi, Universitas Tadulako Palu
}

\begin{abstract}
Abstrak: Penelitian ini merupakan penelitian eksperimental laboratorium dengan tujuan untuk mengetahui efek toksisitas subkronik dan dosis efektif memiliki efek toksik ekstrak etanol uwi banggai ungu (Dioscorea alata L.) dilihat dari parameter kadar SGOT dan SGPT pada tikus putih (Rattus Novergicus). Penelitian ini menggunakan 20 ekor tikus yang dibagi menjadi empat kelompok. Yang terlebih dahulu dilakukan pengambilan darah awal sebagai kontrol normal. Kelompok 1 (Na-CMC 0,5\%), Kelompok $2(200 \mathrm{mg} / 200 \mathrm{gB})$, Kelompok 3 (250mg/ 200gBB) dan Kelompok 4 (300mg/200gBB) ekstrak etanol Uwi Banggai ungu. Semua kelompok diberikan perlakuan yang sama selama 28 hari secara oral. Kemudian pada hari ke 29 dilakukan pengambilan darah akhir secara intracardiac. Pengujian Kadar SGOT dan SGPT menggunakan Photometer $5010_{v 5+}$. Hasil Penelitian menunjukkan nilai rata-rata kadar SGOT kontrol normal 343,82 $\pm 166,94$, Kelompok $1(244,80 \pm 120,85)$, Kelompok $2(412,04 \pm 148,55)$, Kelompok $3(389,16 \pm 98,28)$, dan Kelompok 4 $(368,44 \pm 171,35)$. Nilai rata-rata kadar SGPT kontrol normal 192,25 $\pm 90,30$, Kelompok $1(215,82 \pm 67,04)$, Kelompok 2 (297,84 $\pm 95,78)$, Kelompok $3(410,56 \pm 89,60)$, dan Kelompok $4(290,10 \pm 107,48)$. Hasil statistik dengan menggunakan (One Way ANOVA) dari nilai rata-rata Kadar SGOT dan SGPT diketahui menandakan tidak ada perbedaan bermakna atau biasa disebut non signifikan untuk semua kelompok pengujian, artinya tidak memiliki efek toksisitas subkronik dilihat dari parameter SGOT dan SGPT.
\end{abstract}

Kata kunci: Dioscorea alata L., SGOT, SGPT, Toksisitas, Toksisitas Subkronik

Abstract: This study constitutes an experimental laboratory study aiming to identify the sub-chronic toxicity effect and that the effective dosage has a toxic effect of purple yam (Dioscorea alata L.) ethanol extract as observed from the SGOT and SGPT levels in common rats (Rattus novergicus). This study employed 20 mice divided into four groups. The initial step taken was blood sampling as a normal control. Group 1 (Na-CMC $0.5 \%)$, Group $2(200 \mathrm{mg} / 200 \mathrm{gB})$, Group $3(250 \mathrm{mg} / 200 \mathrm{gBB})$, and Group $4(300 \mathrm{mg} / 200 \mathrm{gBB})$ were given the purple yam ethanol extract. Each group was given the exact treatment orally for 28 days. On the $29^{\text {th }}$ day, the final intracardiac blood sampling was conducted. The SGOT and SGPT level testing used Photometer $5010_{v 5+}$. The result shows that the average value of the normal control of SGOT is $343.82 \pm 166.94$, Group 1 $(244,80 \pm 120,85)$, Group $2(412,04 \pm 148,55)$, Group $3(389,16 \pm 98,28)$, and Group $4(368,44 \pm 171,35)$. The average value of the normal control of SGPT is 192,25 $\pm 90,30$, Group 1 (215,82 $\pm 67,04)$, Group 2 $(297,84 \pm 95,78)$, Group $3(410,56 \pm 89,60)$, and Group $4(290,10 \pm 107,48)$. The statistic result calculated using One Way Anova regarding the average value of the SGOT and SGPT level indicates non-significant difference in each group tested; it means that the sub-chronic toxicity effect is a non-existent as observed from the SGOT and SGPT parameters.

Keywords: Dioscorea alata L., SGOT, SGPT, Sub-chronic Toxicity, Toxicity

\section{PENDAHULUAN}

Uji toksisitas subkronis oral suatu pengujian untuk mendeteksi efek toksik yang muncul setelah pemberian sediaan uji dengan dosis berulang yang diberikan secara oral pada hewan uji (BPOM, 2014).
Uwi banggai ungu termasuk kedalam famili Dioscoreaceae genus Discorea yang memiliki lebih dari 600 spesies yang 10 spesies di antaranya dibudidayakan sebagai bahan pangan dan obatobatan. Tanaman uwi banggai termasuk salah satu marga tanaman yang tidak bisa dipisahkan dengan kehidupan masyarakat Banggai Kepulauan. Hal tersebut disebabkan karena Uwi banggai merupakan

\footnotetext{
* email korespondensi: c_radikasari@yahoo.com
} 
salah satu makanan pokok mereka (Mansur, Barus, \& Madauna, 2015).

Hati merupakan organ yang potensial mengalami kerusaan karena merupakan organ pertama setelah saluran pencernaan yang terpapar oleh bahan-bahan yang bersifat toksik. Sebagai organ detosifikasi hati sangat rentan oleh serangan radikal-radikal bebas. Proses detoksifikasi memungkinkan terbentuknya senyawa-senyawa yang bersifat lebih toksik dibanding senyawa asalnya (Santoso, 2009).

Enzim Serum Glutamat Piruvat Transminase (SGPT) dan Enzim Serum Glutamat Oksaloasetat Transminase (SGOT) adalah dua macam enzim yang dihasilkan oleh sel-sel hati, kedua enzim ini digunakan sebagai indikator pada pemeriksaan hati. Dimana kadarnya akan meningkat dalam darah ketika se-sel hati mengalami kerusakan (Wardani, 2015). Penggunaan dalam jangka waktu yang lama mendorong perlunya penentuan toksisitas subkronik, karena meskipun di anggap aman. Tetapi belum diketahui adanya kemungkinan efek yang tidak diharapkan pada tubuh setelah paparan sediaan uji.

Uwi banggai ungu (Dioscorea alata L.) Dalam penggunaanya sebagai obat tradisional harus di dukung penelitian dan pengujian keamanan, salah satu pengujian yang dilakukan adalah pengujian toksisitas. Namun saat ini belum ada data yang mendukung informasi keamanan mengenai uwi banggai. Oleh karena itu perlu dilakukan pengujian lebih lanjut pada hewan uji untuk melihat ada tidaknya efek toksik terkait informasi parameter Enzim Serum Glutamat Piruvat Transminase (SGPT) dan Enzim Serum Glutamat Oksaloasetat Transminase (SGOT) pada hati dan penggunaan dosis yang tepat serta mengenali tanda-tanda toksik yang terjadi.

\section{METODE PENELITIAN}

Jenis Penelitian. Jenis penelitian ini adalah merupakan eksperimental murni dengan menggunakan Rancangan Penelitian Acak Lengkap dengan pemberian dosis bertingkat ekstrak etanol uwi Banggai ungu (Dioscorea alata L.) melalui oral pada tiap kelompok uji.

Populasi dan Sampel. Populasi penelitian ini adalah seluruh tikus galur wistar yang berada pada satu area. Penentuan besar sampel menurut ketentuan yakni dengan jumlah sampel minimal 5 ekor untuk setiap kelompok perlakuan. (Jusman dan Halim, 2009).

$$
\begin{aligned}
& (\mathrm{n}-1)(\mathrm{t}-1) \geq 15 \\
& (\mathrm{n}-1)(5-1) \geq 15 \\
& (\mathrm{n}-1)(4) \geq 15 \\
& 4 \mathrm{n}-4 \geq 15 \\
& 4 \mathrm{n} \geq 20 \\
& \mathrm{n} \geq 5
\end{aligned}
$$

Dari uraian di atas diperoleh hasil n (Jumlah hewan Uji tiap kelompok) adalah besar dari atau sama dengan 5, sehingga peneliti menggunakan 5 ekor tiap kelompok uji. T pada uraian diatas merupakan banyaknya kelompok uji pada penelitian.

Pengambilan sampel didasarkan pada kriteria inklusi dan eksklusi sebagai berikut:

\section{Kriteria Inklusi}

1. Tikus putih galur wistar

2. Jenis kelamin betina

3. Berat badan $150-250$ gram

4. Umur 2-3 bulan

5. Tingkah laku dan aktivitas normal

6. Tidak ada kelainan anatomi yang tampak

\section{Kriteria Eksklusi}

Tikus tampak sakit (ciri-cirinya yaitu bulu berdiri, kurang aktif, dan mata tidak jernih).

Tahap Penelitian. Penelitian ini terdiri dari beberapa tahap, yaitu:

\section{A. Preparasi Sampel}

Pengambilan dan Pengolahan Sampel. Uwi Banggai ungu diperoleh dari Kabupaten Banggai Kepulauan dideterminasi di Laboratorium Biodiversitas Jurusan Biologi untuk menetepkan jenis uwi Banggainya. Uwi dibersihkan dengan cara mencuci dengan air mengalir untuk menghilangkan partikel berupa tanah dan debu, lalu dikupas untuk memisahkan kulit dengan daging umbi, dipotong kecil melintang, kemudian dikeringkan dengan menggunakan oven pada suhu $55^{\circ} \mathrm{C}$ selama 2 hari.

Ekstraksi Sampel. Simplisia kering uwi banggai yang telah dikeringkan, kemudian dihancurkan menjadi serbuk. Serbuk simplisia uwi Banggai dimasukkan kedalam klongsong, lalu diekstraksi dengan metode soxhletasi dengan menggunakan pelarut etanol 96\%. Ekstraksi dihentikan jika terlihat pelarut pada pipa kapiler soxhlet telah jernih. Ekstrak cair yang diperoleh ditampung lalu dipekatkan dengan menggunakan rotari evaporator hingga diperoleh ekstrak kental.

Skrining Fitokimia Uwi Banggai Ungu. Ekstrak kental yang diperoleh diuji skrining fitokimia untuk mengetahui golongan senyawa yang terdapat dalam ekstrak uwi Banggai ungu. 
B. Pembuatan Pembawa Na CMC 0,5\%. Ditimbang 0,5 g Na CMC kemudian ditaburkan dalam air suling panas lalu dibiarkan mengembang. Selanjutnya, digerus hingga terbentuk mucilago, kemudian dipindahkan ke dalam labu takar dan dicukupkan volume dengan air suling hingga 100 $\mathrm{ml}$.

\section{Pembuatan Sediaan Uji Esktrak Uwi Banggai} Ungu. Pada penelitian ini, digunakan dosis $200 \mathrm{mg} / 200 \mathrm{gBB}, \quad 250 \mathrm{mg} / 200 \mathrm{gBB}$, dan $300 \mathrm{mg} / 200 \mathrm{gBB}$. Pembuatan sediaan uji dosis 200mg/ 200gBB ekstrak uwi Banggai dilakukan dengan cara menimbang ekstrak sebanyak 1,2g ekstrak, Sediaan uji dosis $250 \mathrm{mg} / 200 \mathrm{gBB}$ ekstrak uwi Banggai dilakukan dengan cara menimbang ekstrak sebanyak 1,5g ekstrak, Sediaan uji dosis $300 \mathrm{mg} / 200 \mathrm{gBB}$ ekstrak uwi Banggai dilakukan dengan cara menimbang ekstrak sebanyak $1,8 \mathrm{~g}$ ekstrak. Lalu masing-masing disuspensikan dengan $15 \mathrm{ml} \mathrm{Na} \mathrm{CMC}$ 0,5\% dihomogenkan hingga terbentuk suspensi ekstrak uwi Banggai sebagai sediaan uji.

D. Pengelompokkan dan Perlakuan Hewan uji. Penelitian ini menggunakan 20 ekor tikus yang dibagi dalam 4 kelompok perlakuan. Setiap kelompok perlakuan terdiri dari 5 ekor tikus yang dipelihara dalam kondisi yang sama. Tikus dikelompokkan secara acak sedemikian rupa sehingga penyebaran berat tubuh merata untuk semua kelompok. Hewan uji diaklimatisasi selama 7 hari. Adapun 4 kelompok perlakuan yang dimaksud yaitu:

1. Kelompok Perlakuan 1: diberi Na-CMC 0,5\% secara oral

2. Kelompok Perlakuan 2: diberi $200 \mathrm{mg} / 200 \mathrm{gBB}$ ekstrak etanol Uwi Banggai

3. Kelompok Perlakuan 3: diberi $250 \mathrm{mg} / 200 \mathrm{gBB}$ ekstrak etanol Uwi Banggai

4. Kelompok Perlakuan 4: diberi 300mg/200gBB ekstrak etanol Uwi Banggai

Pemberian ekstrak etanol Uwi Banggai ungu (Dioscorea alata L.) pada tikus putih dilakukan menggunakan sonde lambung dengan dosis tunggal dan dilakukan setiap hari selama 28 hari.

E. Monitoring Berat badan dan Konsumsi Makanan. Monitoring kenaikan berat badan dilakukan setiap hari. Hewan ditimbang setiap hari untuk menentukan volume sediaan uji yang akan diberikan.

F. Pengambilan Darah. Darah diambil menggunakan alat suntik steril dan selalu dijaga agar tidak terkena air (untuk menghindari terjadinya hemolisis). Setelah hewan di anestesi dengan larutan ketamin, darah diambil dari jantung secara perlahan-lahan menggunakan alat suntik steril sebanyak 1-3 mL, satu alat suntik digunakan untuk satu hewan, setelah itu dimasukan kedalam tabung darah yang kemudian akan di uji nilai kadar SGOT dan SGPT nya di UPTD. Laboratorium kesehatan.

\section{HASIL DAN PEMBAHASAN}

\section{Hasil Penelitian}

\section{a. Hasil Identifikasi Tumbuhan}

Identifikasi tumbuhan dilakukan di Laboratorium Biodiversitas Jurusan Biologi, Fakultas Matematika dan Ilmu Pengetahuan Alam, Universitas Tadulako menyetakan bahwa tumbuhan yang digunakan dalam penelitian ini adalah benar uwi Banggai ungu (Dioscorea alata L.) yang diperoleh dari daerah Banggai Kepulauan, Sulawesi Tengah

\section{b. Hasil Pembuatan Ekstrak Etanol Uwi Banggai Ungu}

Hasil proses ekstraksi uwi Banggai ungu menggunakan metode soxhletasi dengan pelarut etanol 96\% diperoleh dari 5971,97 gram simplisia kering dengan hasil ekstrak kental sebanyak 119,96 gram dengan hasil rendemen yang diperoleh yaitu $2,008 \%$. Persentase dari hasil perhitungan rendemen menunjukkan kemampuan pelarut yang digunakan dalam proses penyarian. Persentase rendemen juga dapat digunakan sebagai acuan untuk pemilihan dosis uji.

\section{c. Hasil Penapisan Fitokimia}

Tabel. 1 Hasil Penapisan Fitokimia Ekstrak Uwi Banggai Ungu

\begin{tabular}{cll}
\hline No & Komponen & Hasil \\
\hline 1. & Flavonoid & + \\
2. & Saponin & + \\
3. & Tanin & + \\
4. & Steroid & + \\
5. & Alkaloid & + \\
\hline Keterangan : += Positif mengandung senyawa yang diuji & - = Negatif mengandung senyawa yang diuj
\end{tabular}

\section{d. Hasil Evaluasi nilai kadar SGOT dan SGPT}

Efek toksistas subkronik yang dihasilkan dari perlakuan dapat diketahui dengan melihat nilai kadar darah pada tikus dan diukur menggunakan photometer $5010_{v 5+}$ untuk mengetahui kadar SGOT dan SGPT. Hasil evaluasi toksisitas subkronik dari $\mathrm{Na}$ CMC sebagai kontrol negatif, ekstrak uwi Banggai ungu 200 mg, ekstrak uwi Banggai ungu 
$250 \mathrm{mg}$, dan ekstrak uwi Banggai ungu $300 \mathrm{mg}$ dapat dilihat pada Tabel 2.

Tabel 2. Nilai rata-rata kadar SGOT dan SGPT darah tikus tiap dosis pengamatan menggunakan spektrofotometer photometer $5_{010}$ Setelah Perlakuan Selama 28 Hari

\begin{tabular}{|c|c|c|c|c|c|c|}
\hline \multicolumn{7}{|c|}{ Nilai rata-rata \pm SD kadar SGOT dan SGPT } \\
\hline $\begin{array}{l}\text { Nilai } \\
\text { Kadar }\end{array}$ & $\begin{array}{c}\text { Kontrol } \\
\text { Normal } \\
\text { (U/L) }\end{array}$ & $\begin{array}{c}\mathrm{K}(-) \\
\mathrm{Na}- \\
\mathrm{CMC} \\
(\mathrm{U} / \mathrm{L})\end{array}$ & $\begin{array}{c}\text { EUBU } \\
200 \mathrm{mg} \\
(\mathrm{U} / \mathrm{L})\end{array}$ & $\begin{array}{c}\text { EUBU } \\
250 \mathrm{mg} \\
(\mathrm{U} / \mathrm{L})\end{array}$ & $\begin{array}{c}\text { EUBU } \\
300 \mathrm{mg} \\
(\mathrm{U} / \mathrm{L})\end{array}$ & $\mathbf{P}$ \\
\hline SGOT & $\begin{array}{c}343,82 \pm \\
166,94\end{array}$ & $\begin{array}{c}244,80 \pm \\
120,85\end{array}$ & $\begin{array}{c}412,04 \pm \\
148,55\end{array}$ & $\begin{array}{c}389,16 \pm \\
98,28\end{array}$ & $\begin{array}{c}368,44 \pm \\
171,35\end{array}$ & 0.416 \\
\hline SGPT & $\begin{array}{c}192,25 \pm \\
90,30 \\
\end{array}$ & $\begin{array}{c}215,82 \pm \\
67,04 \\
\end{array}$ & $\begin{array}{c}297,84 \pm \\
95,78 \\
\end{array}$ & $\begin{array}{c}410,56 \pm \\
89,60 \\
\end{array}$ & $\begin{array}{c}290,10 \pm \\
107,48 \\
\end{array}$ & 0,014 \\
\hline
\end{tabular}

\section{Pembahasan}

a. Serum Glutamat Oksaloasetat Transminase (SGOT)

GOT (Glutamat Oksaloasetat Transminase) merupakan suatu enzim aspartat transminase atau aspartat yang terdapat dalam sitoplasma dan mitokondria. Berdasarkan hasil perhitungan rata-rata jumlah nilai kadar SGOT (Tabel 4.2) ekstrak uwi banggai ungu kelompok kontrol negatif (Na CMC 0,5\%) dengan nilai rata-rata dihasilkan $343,82 \pm 166,94 \mathrm{U} / \mathrm{L}$ setelah mendapatkan perlakuan dengan pemberian $(\mathrm{Na}$ CMC 0,5\%) selama 28 hari kadar tersebut menjadi $244,80 \pm 120,85 \mathrm{U} / \mathrm{L}$ dari hasil ini terdapat penurunan kadar dengan rata-rata 99,02 $\pm 46,09$ U/L. Kemudian untuk kelompok 2 Ekstrak uwi banggai ungu kelompok dosis 200mg/ 200 gBB dengan nilai rata-rata dihasilkan 343,82 $\pm 166,94$ U/L setelah mendapatkan perlakuan dengan pemberian dosis $200 \mathrm{mg} / 200 \mathrm{gBB}$ selama 28 hari kadar tersebut menjadi 412,04 $\pm 148,55 \mathrm{U} / \mathrm{L}$ dari hasil ini terjadi peningkatan kadar dengan rata-rata $68,22 \pm 18,39$ U/L. Selanjutnya untuk kelompok 3 Ekstrak uwi banggai ungu kelompok dosis $250 \mathrm{mg} / 200 \mathrm{gBB}$ dengan nilai rata-rata dihasilkan 343,82 $\pm 166,94$ U/L setelah mendapatkan perlakuan dengan pemberian dosis $250 \mathrm{mg} / 200 \mathrm{gBB}$ selama 28 hari kadar tersebut menjadi $389,16 \pm 98,26 \mathrm{U} / \mathrm{L}$ dari hasil ini terjadi peningkatan kadar dengan rata-rata 45,34 $\pm 68,66$ U/L dan untuk kelompok 4 Ekstrak uwi banggai ungu kelompok dosis $300 \mathrm{mg} / 200$ gBB dengan nilai rata-rata dihasilkan 343,82 $\pm 166,94 \mathrm{U} / \mathrm{L}$ setelah mendapatkan perlakuan dengan pemberian dosis 300mg/ $200 \mathrm{gBB}$ selama 28 hari kadar tersebut menjadi $368,44 \pm 171,35 \mathrm{U} / \mathrm{L}$ dari hasil ini terjadi peningkatan kadar dengan rata-rata $24,62 \pm 4,41$ U/L. Dan nilai signifikasi yang didapatkan yaitu 0,416 ( $\mathrm{P}>0,05)$ Dengan pemberian ekstrak untuk seluruh kelompok menandakan tidak ada perbedaan bermakna dalam menaikkan nilai kadar SGOT artinya antara kontrol normal, kontrol negatif $\mathrm{Na}$ CMC 0,5\% dan kelompok perlakuan ekstrak uwi banggai ungu dosis $200 \mathrm{mg}, 250 \mathrm{mg}$, dan 300 mg tidak memperlihatkan efek samping dimana selama 28 hari pemberian ekstrak suspensi uji ini tidak menandakan adanya kerusakan pada hatinya. Hal ini juga dibuktikan dengan analisis ANOVA (Analysis of Variance) yang dilanjutkan dengan uji Duncan menunjukkan bahwa kelompok kontrol normal, kontrol negatif $\mathrm{Na}$ CMC $0,5 \%$ dan kelompok perlakuan ekstrak uwi banggai ungu dosis $200 \mathrm{mg}, 250$ $\mathrm{mg}$, dan $300 \mathrm{mg}$ tidak memiliki perbedaan yang signifikan dengan kelompok uji lainnya. Adapun peningkatan kadar SGOT sesudah perlakuan tidak dikategorikan toksik dari segi parameter SGOT tetapi ada kecendrungan untuk menaikkan nilai kadar SGOT nya dimana apabila terjadi peningkatan 3-10x dari batas normal, kemungkinan terjadi kerusakan hati yang disebabkan oleh virus ataupun penggunaan obat-obatan (Putu, 2016).

\section{b. Serum Glutamat Piruvat Transminase (SGPT)}

GPT merupakan suatu enzim glutamate pyruvat transminase atau Alanin aminotransferase yang terdapat dalam sel parenkim hepar terutama dalam sitosol. Berdasarkan hasil perhitungan rata-rata jumlah nilai kadar SGPT (Tabel 4.2) ekstrak uwi banggai ungu kelompok kontrol negative (Na CMC 0,5\%) dengan nilai rata-rata dihasilkan 192,25 $\pm 90,30 \quad \mathrm{U} / \mathrm{L}$ setelah mendapatkan perlakuan dengan pemberian $(\mathrm{Na}$ CMC 0,5\%) selama 28 hari kadar tersebut menjadi $215,82 \pm 67,04 \mathrm{U} / \mathrm{L}$ dari hasil ini terjadi peningkatan kadar dengan rata-rata 23,57 $\pm 23,06$ U/L. Kemudian untuk kelompok 2 Ekstrak uwi banggai ungu kelompok dosis 200mg/ 200gBB dengan nilai rata-rata dihasilkan 192,25 $\pm 90,30 \quad \mathrm{U} / \mathrm{L}$ setelah mendapatkan perlakuan dengan pemberian dosis $200 \mathrm{mg} / 200 \mathrm{gBB}$ selama 28 hari kadar tersebut menjadi $215,82 \pm 67,04 \mathrm{U} / \mathrm{L}$ dari hasil ini terjadi peningkatan kadar dengan rata-rata 23,57 $\pm 23,06$ U/L. Selanjutnya untuk kelompok 3 Ekstrak uwi banggai ungu kelompok dosis $250 \mathrm{mg} / 200 \mathrm{gBB}$ dengan nilai rata-rata dihasilkan 192,25 $\pm 90,30 \quad \mathrm{U} / \mathrm{L}$ setelah mendapatkan perlakuan dengan pemberian 
dosis 250mg/ $200 \mathrm{gBB}$ selama 28 hari kadar tersebut menjadi $410,56 \pm 89,60 \mathrm{U} / \mathrm{L}$ dari hasil ini terjadi peningkatan kadar dengan rata-rata 218,31 $\pm 0,7$ U/L dan untuk kelompok 4 Ekstrak uwi banggai ungu kelompok dosis 300mg/ 200 gBB dengan nilai rata-rata dihasilkan 192,25 $\pm 90,30$ U/L setelah mendapatkan perlakuan dengan pemberian dosis $300 \mathrm{mg} / 200 \mathrm{gBB}$ selama 28 hari kadar tersebut menjadi 290,10 $\pm 107,48 \mathrm{U} / \mathrm{L}$ dari hasil ini terjadi peningkatan kadar dengan rata-rata $97,85 \pm 17,18$ U/L. Dan nilai signifikasi yang didapatkan yaitu 0,014 ( $\mathrm{P}<0,05)$ Dengan pemberian ekstrak untuk seluruh kelompok menandakan ada nya perbedaan bermakna atau biasa di sebut dengan signifikan dalam menaikkan nilai kadar SGPT dimana dapat dilihat dari analisis lanjutan uji Duncan (Lampiran 6) yang artinya antara kelompok kontrol normal, kontrol negatif $\mathrm{Na} \mathrm{CMC}$ dan kelompok perlakuan ekstrak ubi banggai ungu dosis $200 \mathrm{mg}$, dan $300 \mathrm{mg}$ tidak memperlihatkan efek samping dimana selama 28 hari pemberian ekstrak suspensi uji ini tidak menandakan adanya kerusakan pada hatinya. Hal ini juga dibuktikan dengan analisis ANOVA (Analysis of Variance) yang dilanjutkan dengan uji Duncan menunjukkan bahwa kelompok pemberian sediaan uji kelompok 3 ekstrak uwi banggai ungu dosis 250 mg memiliki perbedaan yang signifikan dengan kelompok uji lainnya. Namun, tidak dikategorikan toksik karena dari segi parameter SGPT tetapi ada kecendrungan dengan meningkatnya dosis maka nilai kadarnya juga meningkat tetapi masih dibatas normal dalam perlakuan selama 28 hari. apabila terjadi peningkatan 3-10x dari batas normal, kemungkinan terjadi kerusakan hati yang disebabkan oleh virus ataupun penggunaan obat-obatan (Putu, 2016).

Namun demikian penelitian ini hanya melihat efek jangka pendek dan nilai kadar SGOT dan SGPT dari pemberian ekstrak uwi banggai ungu pada hati. Sedangkan efek jangka panjang dan pemeriksaan histopatologi pada pemberian ekstrak uwi banggai ungu tersebut terhadap organ hati masih belum diketahui, karenanya masih perlu penelitian lebih lanjut mengenai toksistas kronik dan pemeriksaan histopatologi pada hati.

\section{KESIMPULAN}

1. Ekstrak etanol uwi banggai ungu (Dioscorea alata L.) tidak memiliki efek toksisitas subkronik dilihat dari parameter kadar SGOT dan SGPT pada tikus putih galur wistar dengan pemberian secara in vivo Ekstrak etanol uwi Banggai ungu menandakan tidak ada kerusakan hati yang diakibatkan oleh pemberian ekstrak etanol uwi banggai ungu pada semua kelompok.

2. Tidak ada Dosis efektif dari ketiga dosis uji 200 $\mathrm{mg}, 250 \mathrm{mg}$, dan $300 \mathrm{mg}$ ekstrak etanol uwi banggai ungu (Dioscorea alata L.) yang dapat menimbulkan efek toksik.

\section{DAFTAR PUSTAKA}

Akbar, B. (2010). Antifertilitas, Tumbuhan Dengan Kandungan Senyawa Aktif Yang Berpotensi Sebagai Bahan. Jakarta: Adabia Press.

Anisuzzman, Nazmul, H. Z., Sharmin, S. K., Asuduzzman \& Golam, H. (2016). Antioxidant, Antibacterial Potential and HPLC Analysis of Dioscorea alata BULB.Indonesian J. Pham, 27, 914.

Angelo Josue M. Lubag, Jr., A. C. L. and E. M. T.M. (2008). Antioxidants of Purple and White Greater Yam ( Dioscorea alata L .) Varieties from the Antioxidants of Purple and White Greater Yam, (Juni).

Christina, Y. I., \& I, M. R. (2014). Aktivitas Ekstrak Etanol Umbi Uwi Ungu (Dioscorea alata L.) terhadap Sel B220+IgE+ pada Mencit BALB/c Model Alergi Pencernaan, 98-102.

Hapsari, R. T. (2014). Prospek Uwi Sebagai Pangan Fungsional dan Bahan Diversifikasi Pangan, $38(27), 26-38$.

Harbone, 1987. Tumbuhan Berguna Indonesia Vol 3. Badan Litbang Kehutanan. Jakarta

Helen, O. T., Olusola, A. E., E, I. E., \& Bond, A. U. (2013). (Dioscorea alata L) . Reduces Body Weight by Reducing Food Intake and Fasting Blood Glucose Level, 3(4), 1871-1880.

ITIS. (2018). Dioscorea alata L. Taxonomy serial no 43372. ITIS http://www.itis.gov. Diakses 23 Maret 2018. 
Jusman,S, W., dan Halim, A. (2009). Oksidative Stress in Liver Tissue of Rat Inducet by Cronic Systemic Hypoksia. Makalah Kesehatan, 13 (1,3438).

Khaliq, A. (2016). Uji Toksisitas Akut Ekstrak Etanol Daun Kayu Hitam (Diospyros celebica B.) Terhadap Mencit (Mus musculus).

Nelis lmanningsih , S . T . P ., Ms. (2010). Potensi Tepung Umbi Dioskorea ( Dioscorea alata $L$ ) untuk mencegah Ateros klerosis pada Kelinci Percobaan.

Nurfaat, D. L. (2016). Uji Toksisitas Akut Ekstrak Etanol Benalu Mangga (Dendrophthoe petandra) Terhadap Mencit Swiss Webster. Indonesian Journal of Pharmaceutical Science and Technology, 3(2), 53-65.

Olayinka, E. T., Ore, A., \& Adeyemo, O. A. (2015). Quercetin, a Flavonoid Antioxidant, Ameliorated Procarbazine-Induced Oxidative Damage to Murine Tissues, 304-321. https://doi.org/10.3390/antiox402030

BPOM. (2014). Pedoman Uji Toksisitas Nonklinik Secara In Vivo. Badan Pengawas Obat dan Makanan Repuplik Indonesia

Purnomo, Daryono, B. S., \& , Rugayah, dan I. S. (2012). Studi Etnobotani Dioscorea spp. (Dioscoreaceae ) dan Kearifan Budaya Lokal Masyarakat di Sekitar Hutan Wonosadi Gunung Kidul Yogyakarta, 14(3), 191-198.

Raaman. N., 2006. Phytochemical Techniques. New India Publishing Agensi. India

Sahabu, A., \& Sangadji, M. N. (2015). Upaya Adaptasi Ubi Banggai ( Dioscorea spp ) Jenis "Baku Sombok" Di Daerah Palu Dengan Input Teknologi "Integrated Soil Fertilizer Management," 22(April), 49-56.

Santoso, A. H. (2009). Uji Potensi Ekstrak Ikan Gabus (Channa striata) Sebagai Hepatoprotector Pada Tikus Yang Diinduksi Dengan Parasetamol.
Sari, P. A. M., (2016). Ketoksikan Akut Kombinasi Ekstrak Kelopak Bunga Rosella (Hibiscus sabdariffa L.) dan Daun Jati Belanda (Guazuma ulnifolia Lamk.) dengan Paramater Kadar SGOT dan SGPT Tikus Putih Jantan (Rattus novergicus)

Sentot Budoyo, S. and S. (2010). Kandungan Karbohidrat dan Pola Pita Isozim Pada Varietas Lokal Ubi Kelapa (Dioscorea alata) Di Kabupaten Karanganyar.

Sherwood, 2014, Fisiologi Manusia dari Sel ke Sistem Edisi VIII, EGC, Jakarta.

Sloane, 2004, Anatomy and Physiology, an easy Learner, Diterjemahkan oleh James Veldman, EGC, Jakarta.

Sulaiman Mansur, Henry N. Barus, I. M. (2015). Respon Pertumbuhan dan Hasil Ubi Banggai (Dioscorea alata) Terhadap Pemberian Pupuk Anorganik, Organik Dengan Mulsa Jerami PAdi, 22(2), 131-137.

Trimanto. (2012). Karakterisasi dan Jarak Kemiripan Uwi (Dioscorea alata L.) Berdasarkan Penanda Morfologi Umbi, 15(1), 47-57.

Trustinah. (2013). Karakteristik dan Keragaman Morfologi Uwi-uwian (Dioscorea sp.), 717-726

Wardani, R. N. (2015). Pengaruh Pemberian Ekstrak Etanol Brokoli (Brassica oleracea L. var. italica) Terhadap Kadar SGOT dan SGPT Tikus Wistar yang Diinduksi DMBA.

Yalindua, A. (2014). Potensi Genetik Klon Tanaman Uwi (Dioscorea alata L.) Asal Banggai Kepulauan Sebagai Sumber Pangan Dalam Menunjang Ketahanan Pangan Nasional.

Yesinta Kurniawati. (2016). Toksisitas Subkronis Tablet Fraksi EA-96 Herba Sambiloto ( Andrographis paniculata Nees) Pada Hati dan Ginjal Tikus Wistar. 